\title{
光散乱強度の絕対测定
}

\section{§1. 序論}

1944 年に Debye ${ }^{1}$ が, 稀薄高分子溶液の光散乱の強度 の測定から高分子物質の分子量が決定できることを提唱 してから, 光散乱法は高分子物質研究の重要な方法2?,3) となり，現在では分子量のみならず，溶液中の分子の

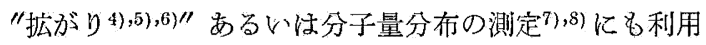
されつつある。

この方法の原理拉よび実験装置, あるいは得られた測 定值の取扱については原諭文1,9) 12) およざ種々の解説

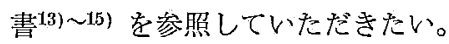

しかし,この光散乱法に掠いては周知のように散乱強 度の絶対值を必要とするが, その求め方はかなりめんど らで困難な問題である。なぜならば一般に散乱光の測定 亿使用される散乱光度計注散乱強度の相対的な值, すな わち使用する装置に固有の単位で測った数值のみを知る ごとく設計されているので, 絶対散乱強度をこの相対值 から求めるには種々の実験的技巧を必要とするからであ る。

篻者 ${ }^{15)}$ はさきに光散乱の実験法についての解説を行 ったが, そこでは実験装置を主とし, 散乱強度の絶対測 定に関してはやや簡略にすぎたので，ここでは散乱強度 の絶対值の測定法および装置の較正法について詳しく述 ベることにする。

\section{§2. 散乱強度の定義と分子量との関係}

光散乱の絶対強度 は種々の方法で表示されているの で, まずそれらの定義を明らかにし, 続いて散乱強度と 分子量の関係に触孔て叔くことにする。

1) Rayleigh ratio： $R$ 一般に純液体などの散乱 強度の表示によく用いられるが次のごとく定義される。

$$
R=\left(i_{90} \cdot r^{2}\right) /\left(I_{0} \cdot V\right)
$$

ここで $i_{90}$ は入射光と直角方向に散乱する散乱光の強度 (エネルギー $\left./ \mathrm{cm}^{2} \cdot \mathrm{sec}\right)$ で $I_{0}$ は入射光の強度, $r$ 注散乱 体積 $V$ の中心から観測点までの距離である（以下の 記述では入射光が自然光の場合および垂直偏向の場合の Rayleigh ratio をそれぞれ $R_{u}, R_{v}$ とするが，特にこ とわらぬかぎり， $R$ には $R_{u}, R_{v}$ のどららをも含める）。

2）濁り度： $\tau$ 高分子溶液の散乱光を表わすのに [150]

\section{山田信夫}

しばしばこの量が用いられている。この“濁り度”こは 大射光が媒質中を透過するとき，その単位進行距離女た りの強度の減少を表わす量であって，次式で与えられ る。

$$
\tau=2 \pi \int_{0}^{\pi}\left(i_{\theta} r^{2}\right) /\left(I_{0} V\right) \sin \theta d \theta
$$

ここで $i_{\theta}$ 柱入射光と $\theta$ なる角度をなす散乱光の強度 である。そして (2) 式で定義された"濁り度”ては が比較的小さな場合には Rambert の法則

$$
I=I_{0} \exp (-\alpha x)
$$

で定義される隇衰率 $\alpha$ に近似的に等しくなる。ここで $I_{0}$ は入射光の強度, $I$ は透過光の強度, $x$ は入射光が媒 質中を進んだ距離である。

3) Rayleigh ratio $R$ と"濁り度" $\tau$ との関係： \& 乙も媒質が，光学的江等方性であって散乱光の強度の角 度 $\theta$ による変化が自然入射光に対して $\left(1+\cos ^{2} \theta\right)$ に比 例する場合には $R$ と $\tau$ とは次の関倸にある。

$$
\tau=(16 \pi / 3) R_{u}=(8 \pi / 3) R_{v}
$$

4) 散乱強度と高分子の分子量との関係： 純液体の 散乱強度沾よび高分子溶液の溶質の示す excess scattering（溶液の散乱強度加ら溶媒のそれを引いたもの） は理論的に次式で表わされる16)。 純液体 $R_{u}=\left(2 \pi^{2} R T \beta / \lambda^{4}{ }_{0} N_{0}\right)(\rho n \cdot \partial n / \partial \rho)^{2}$

$$
\left\{\left(6+6 \sigma_{u}\right) /\left(6-7 \sigma_{u}\right)\right\}
$$

$$
\text { 高分子 }\left\{\begin{array}{r}
R_{u}=\left(2 \pi^{2} c / \lambda^{4}{ }_{0} N_{0}\right)(n \cdot \partial n / \partial c)^{2} \\
\left\{\left(6+6 \sigma_{u}\right) /\left(6-7 \sigma_{u}\right)\right\} \\
\times\left\{1 /\left(2 A_{2} c+1 / M_{2}\right)\right\} \\
R_{v}=\left(2 \pi^{2} c / \lambda_{0}^{4} N_{0}\right)(n \cdot \partial n / \partial c)^{2} \\
\left\{\left(3+3 \sigma_{v}\right) /\left(3-4 \sigma_{v}\right)\right\} \\
\times\left\{1 /\left(2 A_{2} c+1 / M_{2}\right)\right\}
\end{array}\right.
$$

ここで $\lambda_{0}$ は大射光の波長, $N_{0}$ はアボガドロ数, $T$ は温度, $\beta$ は液体の圧縮率, $\rho$ は液体の密度, $n$ は液体 あるいは溶液の屈折率, $c$ 注溶液の濃度， $\sigma_{u}, \sigma_{v}$ はそれ ぞれ自然光および垂直偏光の入射光に対する偏光解消 度, $A_{2}$ は高分子溶液の淩透圧の第 2 ビリアル倸数であ って, $M_{2}$ は溶質高分子の分子量である。

それゆえ (6a) 抢よび (6b) 式加高分子物質の分子 量 $M_{2}$ はં一般的に次のごとく表わされる。

$$
(K c) / R=\left(1 / M_{2}\right)+2 A_{2} c+\cdots \cdots
$$


ここで $K$ は(6a) および (6b) 式のすべての常数を含

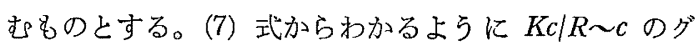
ラフを書けば濃度 $c$ の小さなところでは直線になるの で, この直線の $c=0$ における截片の逆数が高分子物質 の分子量 $M_{2}$ となる。それ河え (7) 式が光散乱による 分子量測定法の基礎公式となる。

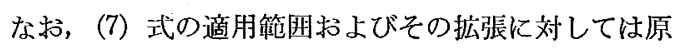
論文:9,11),12),17) 21) を参照されたい。

\section{§3. 散乱光度計の構造}

散乱光を測定する装置（散乱光度計）には種々の原 理(1),22),23) 亿基くものがあり，しかもそれらの各々につ いても種々の型式があるが，現在では光電管方式による 装置がもっぱら使用されている24) 27)。それゆえここで は光電管方式による散乱光度計の構造を測定法の説明に 必要な籁囲で図解的に第 1 図に示す。

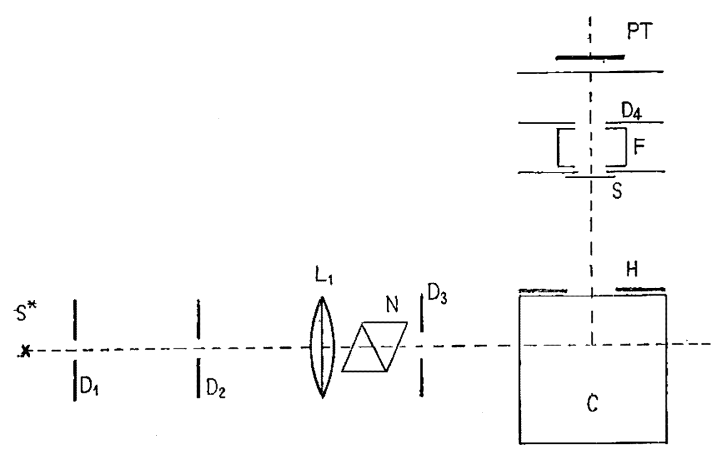

第 1 図 散乱光度計の図式的な構造

第 1 図で $\mathrm{S}^{*}$ は光源, $\mathrm{D}_{1}, \mathrm{D}_{2}$ は絞, $\mathrm{L}_{1}$ はコンデンサ ーレンズで光源 $\mathrm{S}^{*}$ をのレンズの焦点に括き平行光を つる。 $\mathrm{D}_{3}$ は入射光の断面積を定める絞であって，入 射光量を減衰させる Neutral filter はここに着脱する。 $\mathrm{N}$ は入射光垂直に㣂光させるためのニコルプリズム で着脱可能である。C は直方体の試料セルでその受光 部側の側面に $\mathrm{H}$ なるスリットをおく(ここでは絞 $\mathrm{D}_{1}$, $\mathrm{D}_{2}, \mathrm{D}_{3}$ の孔はすべて円形であるとする)。受光部はフィ ルターおよびポーラロイドのためのホルダー F, 受光部 の視野を定めるための絞 $\mathrm{D}_{4}$ 打よび光電管からなり， $\mathrm{PT}$ 忙光電管の光電面を表わす。そしてこの受光部は入射光 の中心を軸として回転できるごとくつくられている。こ のような散乱光度計では光電管の陽極電流は入ってくる 光の量に比例するのでこの電流を適当な方法で測定すれ ば，入射光および散乱光に対応する強度を知ることがで きる。しかしそれらの強度の絶対值は直接には得られな W。

\section{§4. 絕対散乱強度測定法}

前述のように散乱光度計は入射光括よび散乱光の強度 记比例する值（装置の読み）のみしか測定できない。し
かし絶対散乱強度の表示である Rayleigh ratio $R$ ある いは“濁り度”ての定義（1）および（2）式からわかる ように, 入射光と散乱光の比が測定できれば $R$ あるいは ての絶対值を求めることができる。それゆえもし入射光 と散乱光の強度が同程度であるならば散乱光度計の測定 条件を同一にして入射光拉よび散乱光に相当する “装置 の読み” から $i_{90} / I_{0}$ を求めて (1) 式より $R$ を求める ことができる。しかし通常の純液体および高分子溶液の 散乱強度はかなり小さくて, $i_{90} / I_{0}$ は $10^{-6} \sim 10^{-5}$ 程度で あり，しかも散乱光度計は $i_{90}$ 程度の強度の光を測定で きるごとく設計されているので， $i_{90} / I_{0}$ を同一の装置常 数で測定することはできない。そのために $I_{0}$ を既知量 だけ減衰せしめて $i_{90}$ と同程度にする必要がある。以下 ではこの方法による絶対散乱強度の実験法を述べること にする28)。

実際には次のような 3 種の測定を行う。

1）試料セルに被検液を满して散乱光度計の所定の位 置におき, 受光部を入射光と直角方向に掠いて $i_{90}$ に対 応する "装置の読み”を求める。この值を $G_{90}$ とする。

2）試料七儿を除き，受光部を $0^{\circ}$ の位置に掠き，入 射光を Neutral filter により $i_{90}$ 程度まで減率せしめ (このときの Neutral filter の透過率を $T_{0}$ とする) た後の入射光の強さを測定する。このときの “装置の読 み”を $G_{0}$ とする。

3） 2）と同様に Neutral filter により $T_{d}$ だけ入射 光を減少させる。つぎに試料台上に酸化マグネシウムあ るいは炭酸マグネシウムの平面板を入射光と $45^{\circ}$ をす ように掠き，受光部を $90^{\circ}$ 方向に凱いて，この反射板か らの光を測定する。このときの "装置の読み”を $G_{d}$ と する（以下では炭酸マグネシウム板を使用するとして記 述を進める)。

1) の測定から $i_{90}$ に対応する值，2，3）の測定から $I_{0}$ に対応する值が得られるのでこれから $R$ が求められ るが，そのためには散乱光度計の諸常数が必要なのでそ れらを次の記号で表わすことにする。

$J_{0}$ : 入射光の強度, $h_{1}$ : 試料セル側面のスリット $\mathrm{H}$ の 閒除, $h_{2}$ : 絞 $\mathrm{D}_{4}$ の直径, $d_{B}$ : 入射光の 值径, $A_{D}$ : 絞 $\mathrm{D}_{4}$ の断面積 $\left(\pi h_{2}^{2} / 4\right), A_{B}$ : 入射光の断面積 $\left(\pi d_{B}^{2} / 4\right), r$ : 散 乱体積の中心から $\mathrm{D}_{4}$ までの距碓, $r_{f}: \mathrm{MgCO}_{3}$ 板の全 反射率。

ところで "装置の読み” は光電管に入る光量に比例す るから次式が成立する。

$$
\begin{gathered}
G_{90}=k i_{90} A_{D}=\left(k R I_{0} / r^{2}\right) \\
=\left(V A_{D}\right) \\
G_{0}= \begin{cases}\left.k J_{0} T_{0} R / r^{2}\right) & \left(h_{1} A_{B} A_{D}\right) \\
\left(k J_{0} T_{0} A_{D}\right) / A_{B} & A_{D} \geq A_{B} \leq A_{B}\end{cases}
\end{gathered}
$$

ここで $k$ は装置の感度を表わす常数である。

また $G_{d}$ に対する表示を得るには次のごとくする。い 
ま $\mathrm{MgCO}_{3}$ 板が理想的な diffuser であるとすると次式 が成立する。

$$
d G(\theta)=k\left[(K \cos \theta) / r^{2}\right] d A
$$

(10) 式で $\theta$ は $\mathrm{MgCO}_{3}$ 板の法線 と観測線のなす角度 で, $d G(\theta)$ は $\mathrm{MgCO}_{3}$ 板の入射点から距離 $r$ にある球 面の一部 $d A$ に到達する光量であって，K注数であ る。したがって常数 $K$ は次式で計算される。

$$
\int d G(\theta)=K J_{0} r_{f} T_{d}
$$

ここで積分は半径 $r$ の半球面についてなされるとする。

実際の測定 3) の場合には $A_{D}$ 上のすべてい点が $\mathrm{MgCO}_{3}$ 板の入射点から等距離 $r$ にある仮定して $A_{D}$ 面内の積分を行うと（11）式より次式が得られる。

$$
G_{d}=k\left(0.707 / \pi r^{2}\right) J_{0} r_{f} T_{d} A_{D}
$$

$J_{0}=I_{0} A_{B}$ であるから (8) および (12) 式から $J_{0}$ を 消去し (1) 式を用いると

$$
R=\left(0.707 r_{f} / \pi h_{1}\right) T_{d}\left(G_{90} / G_{d}\right)
$$

また（8）および（9）式より

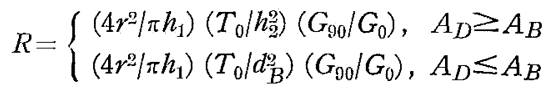

が得られる。

(13) および $(14 \mathrm{a}, \mathrm{b})$ 式によって $i_{90}$ と $I_{0}$ に対忍す る相対值 $G_{90}$ および $G_{0}$ あるいは $G_{d}$ の測定から絶対 散乱強度 $R$ が求められる。(14a, b) 式によって $R$ が求 められるので，ことさらに $\mathrm{MgCO}_{3}$ 板などを用いる複 雑な方法で $G_{d}$ を求めなくても原理的にはよいわけであ るが，(13) 式と $(14 \mathrm{a}, \mathrm{b})$ 式との比較からわかるように， (13) 式には装置常数として $h_{1}$ だけが必要であるに反し て (14a, b) 式には $h_{1}$ のほかに $h_{2}$ あるいは $d_{B}$ なる装 置常数が 2 乗の形で余分に入っている。そのために $h_{2}$, $d_{B}$ をより精密に測定せね壮はらぬ不便がある。また $G_{0}$ を測定するときの Neutral filter の透過率 $T_{0}$ と $G_{d}$ を 測定するときの $T_{d}$ とは実際には $T_{0} \simeq T_{d} \times 10^{-3}$ の関 係にあるので, $T_{0}$ は非常に小さな值となる。このよう に小さな透過率を実測により直接検定して抽くことは非 常にむずかしく誤差が多い。この点でも（13）式を用い て $R$ を求める方法の方が便利である。

4) 補正因子，（13）招よび (14a,b) 式の誘導は受光 部が試料と同じ屈折率の媒質中にあると仮定してなされ た。

すなわち試料セルの壁のこころで散乱光線が屈折しな いと仮定している。しかし現実には試料セルの壁で散乱 光線の屈折が起るのでこれに対する次のような補正が必 要こなる。

a) 届折が起ると $G_{90}$ に寄与する試料の散乱体積 $V$ は $A_{B} h_{1}$ ではなくなる。このことに対する補正を体積 補正因子 $C_{v}$ で表わす。

b) 散乱体積中の 1 点から散乱する光束は屈折のない 場合よりも小さな角度に制限される。これに対する補正

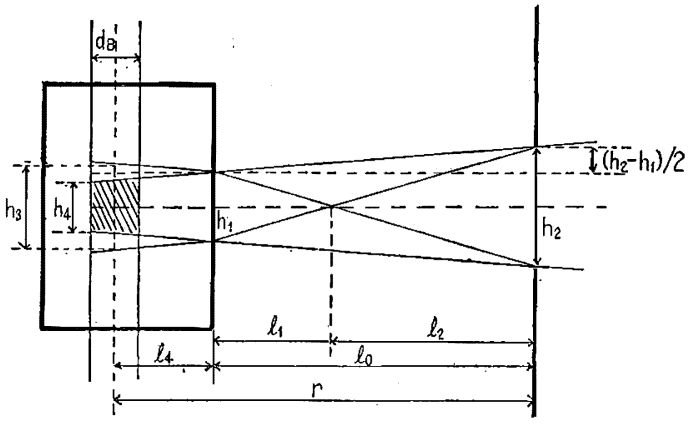

第 2 図 体積補正因子 $C_{v}$ を表わす図式 (試料セルを上部からみた図)

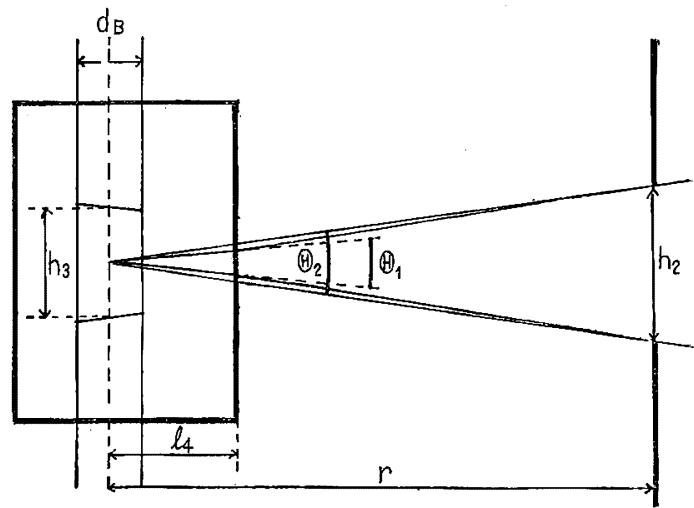

第 3 図 屈折率補正因子 $C_{n}$ を表わす図式 (試料セルを上部汃らた図)

を屈折率補正因子 $C_{n}$ で表わす。このありさまはそれぞ れ第 2,3 図に図解的に示されている（図では試料セル の壁の厚さは無視している)。

第 2 図から知られるよらに斜線の部分からの散乱光は 光電面に完全に笴与するが, $h_{3}$ と $h_{4}$ の閒の部分からの 散乱光は完全には寄与しない。い亡この部分の寄与の割 合が光束の中心からの距離に比例して減少すると仮定す ると散乱体積の有效長は $h_{1}$ ではなしに $\left(h_{3}+h_{4}\right) / 2$ と なる。それゆえ体積補正因子 $C_{v}$ は次式で表わされる。

$$
C_{v}=2 h_{1} /\left(h_{3}+h_{4}\right)
$$

Carpenter, Krigbaum ${ }^{28)}$ の計算によれば $h_{3}, h_{4}$ は次 のよらに表わされる。

$$
\begin{aligned}
& h_{3}=h_{1}+\left(2 l_{4}\right) /\left[n^{2}\left\{1+\left[2 l_{0} /\left(h_{2}+h_{1}\right)\right]^{2}\right\}-1\right]^{\frac{1}{2}} \\
& h_{4}=h_{1}-\left(2 l_{4}\right) /\left[n^{2}\left\{1+\left[2 l_{0} /\left(h_{2}-h_{1}\right)\right]^{2}\right\}-1\right]^{\frac{1}{2}}
\end{aligned}
$$

(15)，(16)，(17）式からわかるよらに， $l_{4}$ すなわち大射 光束の中心と試料の壁との閒の距離を小さくすれば $C_{v}$. を 1 に近くすることができる。事実実際の散乱光度計で は $l_{4}$ は $l_{0}$ に比してかなり小さいので届折率 $n$ が非常 に大きな液体でないかぎり，さほど 1 とは異ならない。 ただ Maron および Lou29) らは（16)，(17）式とは異. なる体積補正因子の係数を導いている。しかし届折率 $n$ の異なる液体に対する $C_{v}$ の比は (15), (16), (17) 式か ら計算したものとほとんど一致しているので, ここでは 
Krigbaum の結果を採用しておいた。

屈折率補正因子 $C_{n}$ は $C_{v}$ よりも重要であるが，こ れに対する計算式は各研究者により異なった式が提出さ れていて，一般式は明確でない16),307,31)。しかしそれら の結果索参照してみるに, $C_{n}$ が $\left(l_{4} / r\right)$ と試料セルの形 に依存することだけは確かのようである。

Carr および Zimm ${ }^{16)}$ の直方体セルに対する計算に よれば $C_{n}$ は次式で表わされる（第 3 図参照）。

$$
\left[C_{n}\right]_{L}=\left(\Theta_{2} / \Theta_{1}\right)^{2}=n^{2}\left[1-\left\{l_{4}(n-1)\right\} / r n\right]^{2}
$$

また，名れらは直方体セル，球形七ル， 円筒形七ルに 同一の試料を満してそれらの $i_{90}$ 亿対応する測定值の比 から実験的に球形および円筒形セルに対する $C_{n}$ の形を 求めた。その結果によれば球形セルに対しては $\left[C_{n}\right]_{s}=1$, 円筒形セルに対しては $\left[C_{n}\right]_{C}=\left\{\left[C_{n}\right]_{L}\right\}^{\frac{1}{2}}$ である。

このような補正因子 $C_{v}, C_{n}$ はいずれも $G_{90}$ の測定 のみに必要であるから，補正因子を考慮した $R$ の公式 は次のごとくなる。

$$
\begin{aligned}
& R=\left(0.707 r_{f} / \pi h_{1}\right) T_{d}\left(G_{90} / G_{d}\right) C_{n} C_{v} \\
& R=\left\{\begin{array}{l}
\left(4 r^{2} / \pi h_{1}\right)\left(T_{0} / h_{2}^{2}\right)\left(G_{90} / G_{0}\right) C_{n} C_{v} \\
\left(4 r^{2} / \pi h_{1}\right)\left(T_{0} / d_{B}^{2}\right)\left(G_{90} / G_{0}\right) C_{n} C_{v}
\end{array}\right.
\end{aligned}
$$

なおこれらの公式中に表われる $T_{0}, T_{d}$ なる Neutral filter の透過率㧤よび $\mathrm{MgCO}_{3}$ の全反射率 $r_{f}$ は既知之 して取り扱ったが実際の測定にあたっては， $T_{0}, T_{d}$ は 分光光度計などにより測定波長に対して検定しておく必 要がある。 $r_{f}$ に対しては Benford ${ }^{32)}$ らの測定があって

$$
\begin{aligned}
& r_{f}=0.965(4360 \AA) \\
& r_{f}=0.980(5460 \AA)
\end{aligned}
$$

なる結果が得られているのでこれを利用するとよい。

\section{§5. 散乱光度計の較正法}

前述したように光散乱強度の絶対值の測定法はかなり

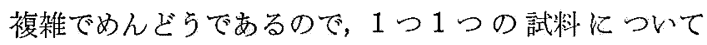
§4の方法を採用するのは便利ではない。それで散乱強 度既知の液体 (純液体あるいは標準ポリスチレンの溶液)

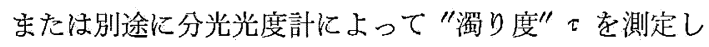
たものを標準液として，これの $i_{90}$ に対応する值を測定 して, この測定值と絶効散乱強度との比例常数を定めて 散乱光度計を較正することもしばしば行われるのでこれ について述べることにする33)〜35)。

分光光度計により標準液の “濁り度” $\tau$ を求めるには 次のようにする。なるべく長い試料セル(通常 $10 \mathrm{~cm} の$ セルが用いられる）に標準液を満す。このときの標淮液 としてはやや濁り度の高い高分子溶液（たとえばポリス チレンのトルェン溶液に少量のメチルアルコールを混ぜ たもの）あるい滺濁液（ポリスチレンエマルジョン， Ludox など)が用いられる。そして人射光がこの標淮液 を通過する前後の值を測定し，それらを $G_{0}, G_{T}$ とすれ ば（3）式より

$$
\tau=(1 / x) \ln \left(G_{0} / G_{T}\right)
$$

が得られて “濁り度”てが求められる(必要なればてを $R$ になおすこともできる。(4) 式を使用。ただし光学的 に等方性でないものを標準液として使用したときには (4) 式は成立しないことに注意)。

この標準液の $i_{90}$ に対応する "装置の読み” を散乱光 度計を使用して測定しその值を $G_{90}$ とする。 $G_{90} に C_{n}$, $C_{v}$ の補正をなした值を $G_{90}^{\prime}$ とすると以上 2 つの測定 加

$$
\tau=A G^{\prime}{ }_{90}
$$

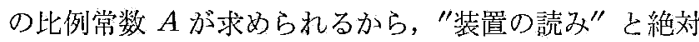
散乱強度との関係が定まり,散乱光度計の較正ができる。

しかしこの方法に用いる標準液にかなりの濁り度がな いと $G_{0}$ と $G_{T}$ との差がほとんどなくなり， $G_{0}, G_{T}$ を 非常に精密に（有効数字 5 6 桁の精度）測定しないと ての絶刘值に大きな誤差を与える。そのために前述のよ らな割合に“濁り度”の大きな液を標準液として用いる のである。

しかしながらこのようにてのかなり大きな液を標準 液として用いると（2）式で定義される $\tau$ と（3）式で 定義される $\alpha$ とは近似的にも等しいとみなせなくなる。 そのために (20) 式の常数 $A$ がての大きさによって 変化するようになる。これに対する検討を加えたものに Lou ${ }^{35)}$ らの研究がある。かれらの研究によれば次のご とく考えられる。

(1) 式辂よび (4) 式から $i_{90}$ とてとの関倸法次式で 表わされる。

$$
\tau=\left(16 \pi r^{2} / 3 V\right)\left(i_{90} / I_{0}\right)
$$

しかしこの関係は体積 $V$ 中で入射光の強度が一定であ る場合にのみ悠密に成立する。ところがてが大きくな ると入射光の強度 $I_{0}$ は (3) 式に従って減衰し前述の仮 定が近似的にも満されなくなる。また散乱光も途中にあ る濁った液体のために同様の減衰を受ける。以上の 2 つ の理由のためにての大きな場合には (20) 式の常数 $A$ がての函数となるのである。このことを考慮しててと $i_{90}$ との関係を書きなおする（第 2 図参照）次式が得ら れる。

$$
\tau=\left(16 \pi r^{2} / 3 V\right)\left\{i_{90} \exp \left(\tau I_{4}\right) / I_{0} \exp \left(-\tau l_{5}\right)\right\}
$$

ここで $l_{5}$ は入射光が試料セルを通る有效距離である。 (21) 式を書きな掠すと

$$
\begin{gathered}
\log \left(\tau / i_{90}\right)=k_{1}+k_{2}=. \\
k_{1}=\log \left(16 \pi r^{2} / 3 V I_{0}\right), \quad k_{2}=\left(l_{4}+l_{5}\right) / 2.303
\end{gathered}
$$

となって, より精密な $\tau$ と $i_{90}$ との関係式が得られる。 それであるから"濁り度”てのかなり大きな液を標準 液として使用する場合には，ての翼なる数種の液のて䄦 よび $G_{90}^{\prime}$ を前述の方法により測定して $\log \left(\because / G_{90}^{\prime}\right) \sim \tau$ のグラフをつくり,これより (22) 式の $k_{1}, k_{2}$ を最小 2 乘法で求め, こ机方 $\left(\tau / G_{90}^{\prime}\right) \sim G_{90}^{\prime}$ の較正表をつくっ 
ておくことが必要である（なおこの較正表は入射光の波 長によって変化するから, 散乱強度測定に使用する各波 長に対応する較正表がそれぞれ必要である)。

なおこの他にベンゼン，トルエンなどの純液体の緦対 散乱強度はすでに多くの研究者により測定されているの でこれを既知のものとして，(20) 式を用いて散乱光度 計の較正をすることもできる。ただこの場合には使用す る液体を完全に光学的に清浄にして预かぬと大きな誤差 が入るから特に試料の精製，清浄化に留意しなければな らない。

\section{§6. 純液体の散乱強度}

これまでの記述からもわかるように，光散乱法により 得られる高分子物質の分子量の正確さほ第 1 亿散乱強度 測定の正確さに支配される。それゆえ各研究者による純 液体の散乱強度の測定值の一致の程度を知ることはむた

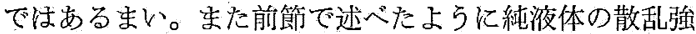
度を既知として散乱光度計を較正することもできるの で，純液体の散乱強度の測定值を集録しておくことも意 味があると思われる。

数年前まで純液体としてベンゼンに対する散乱強度の 測定值が測定者により大きく異なり，第 1 表に示すよう

第 1 表 ベンゼンの絶対散乱強度 $\left(R_{u}\right)$

\begin{tabular}{c|c|c}
\hline \multicolumn{2}{|c|}{$R_{u} \times 10^{6}$} & \multirow{2}{*}{ 文 献 } \\
\cline { 1 - 2 }$\lambda_{0}=4360 \AA$ & $\lambda_{0}=5460 \AA$ & $46)$ \\
31.8 & - & $47)$ \\
34.8 & - & $48)$ \\
29.1 & 11.8 & $49)$ \\
- & 11.8 & $50)$ \\
31.5 & 11.6 & $36)$ \\
27.8 & 10.4 & $51)$ \\
28.0 & - & $16)$ \\
48.5 & 16.3 & $52)$ \\
48.2 & 16.4 & $53)$ \\
48.4 & 17.6 & $54)$ \\
48.4 & - & $55)$ \\
47.1 & - & $56)$ \\
46.3 & - & $29)$ \\
49.7 & 17.2 & $40)$ \\
46.0 & 16.9 & $28)$ \\
50.0 & 15.7 & \\
\hline
\end{tabular}

に大きく 2 つの稀に分れ (いわ沛る low value と high value), しかもそれぞれの群の中の值は実験誤差の範囲 内でほとんど一致するという奇妙な現象を呈した。

これに関しては実にさまざまな議諭36) 399 繰返さ扎 たが，結局使用した散乱光度計の構造上の久点のために 異常に小さな散乱強度の測定值が得られたのだといら結
論に到達したのが 1956 年に入ってからのことであ $\Xi^{28), 40)}$ 。

そこでここではこれまでに測定されたいくつかの紣 液体の散乱強度の絶対值のうちから，、わゆる high value school 亿属する值を第 2 表集録して扝く。

第 2 表 純液体の絶対散乱強度

\begin{tabular}{|c|c|c|c|}
\hline \multirow{2}{*}{ 物 } & \multicolumn{2}{|c|}{$R_{u} \times 10^{6}$} & \multirow{2}{*}{ 文 献 } \\
\hline & $\lambda_{0}=4360 \AA$ & $\lambda_{0}=5460 \AA$. & \\
\hline \multirow{3}{*}{ 水 } & - & 1.05 & 59) \\
\hline & - & 0.97 & 60) \\
\hline & 2.89 & 1.05 & 61) \\
\hline \multirow{2}{*}{ トルェン } & 60.3 & 20.5 & 29) \\
\hline & 60 & 21 & 28) \\
\hline \multirow{4}{*}{ 四塩化炭素 } & 15.8 & 5.9 & 16) \\
\hline & 15.4 & 5.8 & 40) \\
\hline & 25.0 & 8.9 & 29) \\
\hline & - & 5.6 & 57) \\
\hline \multirow{3}{*}{ 二硫化炭素 } & - & 70 & 57.) \\
\hline & 225 & 70 & 58) \\
\hline & 158 & 一 & 16) \\
\hline
\end{tabular}

これで見ると各研究者の測定值の一致はかなりよく， 光散乱法による分子量決定の精度は他の滲透圧法, 超遠 心法に比してもかなりよいと思われる（直接これらの方 法の信頼性を検討したものに Flank ${ }^{3)}$ らの総合研究の 報告があるが，これによっても光散乱法の精度任他の方 法よりかなりよいようである)。

なお high value school と low value school との 測定值の差異をめぐって，散乱強度測定のときに特に注 意すべき点がかなり明確になったので，これを次節で述 ベることにする。

\section{§ 7． 散乱光の絕対測定に詨する注意}

1）散乱光度計の構造に対する注意

光電管，とくに現在広く使用されている二次電子増倍 光電管 (P.M.) を利用した散乱光度計で散乱光を測定 する場合, 光電面の位置によりその感度が非常に異な る ${ }^{41,429)}$ ため，これに対する顧慮をはらって装置を設計 してないと前節で述べたように散乱強度に大きな證差を 生ずる。

二次電子増倍光電管の光電面の位置による威度変化の 例定第 4 図に示す+2)。

このように光電面の威度が位置により異なると入射光 と散乱光の強度 $I_{0}$ および $i_{\theta}$ を測定するとき, 両者の像 の光電面上の位置と大きさが全く同一であることが望ま しい。しかし入射光惊通常平行光線であるから絞 $\mathrm{D}_{4}$ の 断面積 $A_{D}$ 亿上って人射光の像の面積が定まるが $\left(A_{D} \leq\right.$ 


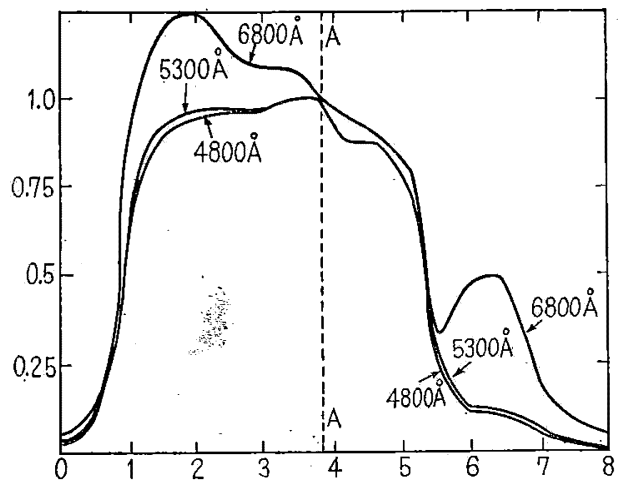

〔縦軸：AAの位置で規格化した相対感度, 横軸 : 光 電面の位置 (端を原点として mm で表わしてある)】

第 4 図 二次電子増倍光電管 $(931-\mathrm{A})$ の感度の光電面の位置による変化

$A_{B}$ のとき), 散乱光測定のときは第 2,3 図からわかる ようにこれは散光であるから $A_{D}$ よりも大きな面積の 像をつくる。それゆえ $A_{D}$ が装置の諸常数によって定 まるある大きさ以上になると散乱光の像が光電面よりも 大きくなり，散乱光の一部しか測定できぬ場合も起り得 る。またそれほど極端な場合でなくても感度の低い光電 面の端に当った 散乱光 は小さな 光電流しか生ぜしめな W.

このような不都合を除くためには絞 $\mathrm{D}_{4}$ の面積 $A_{D}$ を 小さくするか28), (0)，あるいは $\mathrm{D}_{4}$ の位置に凸レンズを おいて散乱光を収束して光電面に入射せしめるか11),16), あるいは光電面の前面に 乳色ガラスを扮き24),26) これの 明るさを光電管で測定するよらにすればよい。

2）その他の注意

光散乱実験に必要な一般的な注意事項は原論文 ${ }^{25), 43) 〜 ~}$ 45）あるい任解説書13)〜15) を参照していただきたいが, 散乱強度の絶対值を測定する場合に怕体積補正因子 $C_{v}$, 屈折率補正因子 $C_{n}$ を装置の諸常数抒よび試料の屈折率 から計算して必ずこの補正をほどこすことが必要であ る。

\section{§8. 結 び}

以上で光散乱による高分子研究の基礎である散乱强度 の絶対值の測定法の解説を終る。使用する散乱光度計が 第 1 図のものと異なれば多少測定法の細部に変更がある が，基本的な実施法は一応紹介し得たよらに思われる。 しかし筆者の不勉強のため不備な点があるかもしれない ので，それらに対して御批判をいただければ幸である。

(電気通信研究所物理研究室)

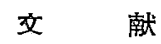

1) P. Debye: J. Appl. Phys., 15, 338 (1944)

2) "International Union of Pure and Applied Chemistry"; J. Polym. Sci., 10, 129 (1953)
3) H. Frank and H. Mark: J. Polym. Sci., 17, 1 (1955)

4) F. Billmeyer Jr.: J. Am. Chem. Soc., 75, 6110 (1953)

5) P. Outer, C. I. Carr and B. H. Zimm: J. Chem. Phys., 18, 830 (1950)

6) N. T. Notbey and P. J. W. Debye: J. Polym. Sci., 17, 99 (1955)

7) H. Benoit, A. M. Holtzer and P. Doty: J. Phys. Chem., 58, 624 (1954)

8) L. D. Moore: J. Polym. Sci., 20, 137 (1956)

9) P. Debye: J. Phys. \& Colloid Chem., 51, 18 (1947)

10) G. Oster: Chem. Rev., 43, 319 (1948)

11) B. H. Zimm: J. Phys. Chem., 16, 1093, 1099 (1948)

12) P. Doty and R. F. Steiner:- J. Chem. Phys., 18, 1211 (1950)

13) P. J. Flory: "Principles of Polymer Chemistry" 283

14）稻垣博, 尾山外茂男：高分子,1, No. 8, 24； 1, No. 9, 20 (1952) ; 2, No. 2, 49 (1953)

15）山田信夫：実験化学講座, 高分子化学, 93

16) C. I. Carr and B. H. Zimm: J. Chem. Phys., 18, 1616 (1950)

17) H. C. Brinkman and J. J. Hermans: J. Chem. Phys., 17, 574 (1949)

18) J. G. Kirkwood and R. J. Goldberg: J. Chem. Phys., 18, 54 (1950)

19) W. H. Stockmayer: J. Chem. Phys., 18, 58 (1950)

20) H. Benoit: J. Polym. Sci., 11, 507 (1953)

21) H. Benoit and P. Doty: J. Phys. Chem., 57, 958 (1953)

22) P. P. Debye: J. Appl. Phys., 17, 392 (1946)

23) R. Stein and P. Doty: J. Am. Chem. Soc., 68, 159 (1946)

24) R. Speiser and B. A. Brice: J. Opt. Soc. Am., 36, 364 (1946)

25) R. Blaker, R. Badger and T. Gilman: J. Phys. \& Colloid Chem., 53, 794 (1949)

26) B. A. Brice, M. Halwer and R. Speiser: $J$. Opt. Soc. Am., 40, 768 (1950)

27) P. Bosworth, C. R. Masson and H. W. Melville : J. Polym. Sci., 9, 565 (1952)

28) D. K. Carpenter and W. R. Krigbaum: $J$. Chem. Phys., 24, 1041 (1956)

29) S. H. Maron and R. L. Lou: J. Polym. Sci., 14, 273 (1954)

30) J. J. Hermans and S. Levinson: J. Opt. Soc. Am., 41, 460 (1951)

31) D. J. Meier: J. Chem. Phys., 21, 1892 (1953)

32) F. Benford et al: J. Opt. Soc. Am., 38, 445, S64 (1948)

33) G. Oster: J. Polym. Sci., 9, 525 (1952)

34) W. F. M. Mommarrts: J. Colloid Sci., 7, 71 (1952)

35) S. H. Maron and R. L. Lou: J. Polym. Sci., 14, 29 (1954) 
36) K. F. Stamm and P. A. Button: J. Chem. Phys., 21, 1304 (1953)

37) M. Halwer, G. C. Nutting and B. A. Brice: J. Chem. Phys., 21, 1425 (1953)

$38)$ B. H: Zimm: J. Polym. Sci., 10, 351 (1953)

39) A. Rousset and R. Lochet: J. Polym. Sci., 10, 319 (1953)

40) R. F. Stamm and P. A. Button: J. Chem. Phys., 23, 2456 (1955)

41) T. F. Godlove and W. G. Wadey: Rev. Sci. Instr., 25, 1 (1954)

42) H. Edels and W. A. Gambling: J. Sci. Instr., 31, 121 (1954)

43) D. A. I. Goring and P. Johnson: Trans. Faraday Soc., 48, 367 (1952)

44) 稲垣博, 野口肇：物性論研究, No. 50, 64 (1952)

45) C. Thurmond: J. Polym. Sci., 7, 607 (1952)

46) Martin and Lehman: J. Chem. Phys., 27, 558 (1922)

47) P. Peyrot: Comp. rend., 203, 1512 (1936)

48) Sunanda: Proc. Ind. Acad., 15, 357 (1942)

49) G. de Vaucouleurs : Comp. rend., 229, 35 (1950)

50) G. de Vaucouleurs: Ann. Phys., 6, 213 (1951)

51) M. Harrand: Ann. Phys., 8, 646 (1953)

52) P. Doty and R. F. Steiner: J. Chem. Phys., 18, 1218 (1950)
53) B. A. Brice and M. Halwer: J. Opp. Soc. Am., 40, 765 (1950)

54) A. Oth, J. Oth and V. Desreux: J. Polym. Sci., 10, 551 (1953)

55). G. Oster: Ann. Chem., 25, 1165 (1953)

56) J. Kreman and J. J. Spapiro: J. Opt. Soc. Am., 44, 500 (1954)

57) J. J. Hermans : Rec. Trav. Chim., 73, 273 (1954)

58) B. Sedacec: Chem. Listy., 47, 1120 (1953)

59) D. A. I. Goring and P. G. Napier: J. Chem. Phys., 22, 147 (1954)

60) R. W. Fressenden and R. S. Stein : J. Chem. Phys., 22, 1778 (1954)

61) J. Kraut and W. B. Dandliker: J. Chem. Phys., 1544 (1955)

従来, 高分子研究論文集注海外よりの交換誌または購 読に応じて来ましたが, 最近「高分子」に拉いても，ドイ ッ,イギリス，ソ連，米国など十数为国より直接申込を 受ける外，また大安文化貿易, 日本海外出版貿易, ナウカ （株）の書店を通じ每月 250 部に余る依頼を受けました。 これ一に当学会が世界科学者の注目を浴びつつある証左 であり，誠に御同慶に堪えません。ここに全会員に御連 絡するわけです。

会誌「高分子」は時局の要請もあってか, 依然毎月会員激増の状況でありますが, 研究論文集「高分子化学」 の会員増加はその3 分の1であります。しかし一方, いい研究論文が全国から続々集って参り, 審査委員諸公 も御多忙中にすか加わず迅速潘查をして下さいます。こんなわけで, 今月号 (下記第 141 号) は諸経費の 増大を承知の上で，犠牲的に5割の増ページ定断行してみました。毎月でもやりたいわけですが，なかなか経 費が許しません。研究論文の会員数の増加が今より顕著になれば，さらに部厚のものが毎月でもできる計算に なります。御承知のごとく, 研究論文集は高分子の物理, 化学, 基礎工学, 医農学の本邦最高水準を期してお り, 諸外国へも数百冊送付されている次第でありまして, 高分子科学の研究者にとっては無二の伴侶であると 確信しております。会員相互のため, 増ページが反復できるよう会員の増大に御協力下さい。

研究論文集

$$
\begin{gathered}
\text { 高分子化 学目 次 } \\
\text { 第 } 14 \text { 巻・第 } 141 \text { 号・1957 }
\end{gathered}
$$

[物理]

[1] ポリエチレンアジペートの球晶に関する研究

第 1 報 球晶の生成過程とクラックの発生について…….............................増 沢

[2]繊維の誘電的研究

第 1 報 低周波電場に㧍ける繊維の誘電的測定とその解析について

[化学]

[3] 繊維処理剤に関する研究

第 1 報 PVA によるアクリロニトリルの乳化重合について…....................鵬 川 博，美

[4〜5] アクリロニトリルの重合に関する研究

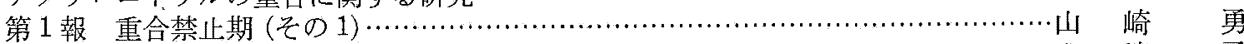

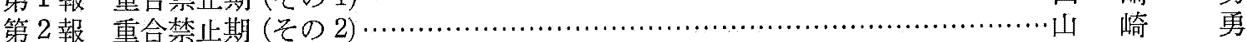

[6７］金属ナトリウムによる重合反応の研究

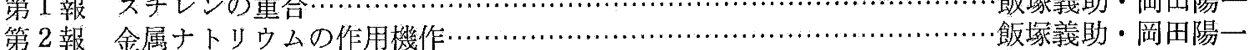

[ 8 ] ポリビニルアルコール部分酢化物の水溶液の相平衡…….................桜田一郎・坂口康義 ·伊藤順夫

[9] アクリロニトリル系合成繊維に関する研究

第 26 報 レドックス重合に関する一考察

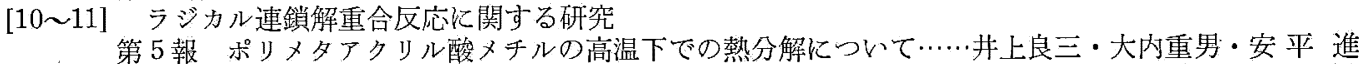

第 6 報 スチレンメタクリル酸メチル共重合物の熱分解について…‥牛上良三・大内重男・安平 進 